\title{
Shift in seagrass food web structure over decades is linked to overfishing
}

\author{
Susanne Baden ${ }^{1, *}$, Andreas Emanuelsson ${ }^{1,2}$, Leif Pihl ${ }^{1}$, Carl-Johan Svensson ${ }^{3}$, \\ Per Åberg ${ }^{3}$
}

${ }^{1}$ Department of Marine Ecology, University of Gothenburg, Kristineberg, 45178 Fiskebäckskil, Sweden

${ }^{2}$ SIK - Swedish Institute for Food and Biotechnology, 40229 Gothenburg, Sweden

${ }^{3}$ Department of Marine Ecology, University of Gothenburg, 40530 Gothenburg, Sweden

\begin{abstract}
Empirical field studies in seagrass have revealed that overgrowth by filamentous algae which reduces seagrass growth can be explained by a top-down cascading effect caused by declines in top predators, which is enforced by eutrophication. On the Swedish west coast, $60 \%$ of the seagrass has disappeared since the 1980s. We hypothesised that overfishing, responsible for a $>90 \%$ decline in the cod stock, and the 4 to 8 times increase in nutrient load since the 1930s have altered the seagrass structure and function during recent decades. We used quantitative samples from the 1980s and 2000s and analysed the trends in abundance of the 4 feeding guilds: top predatory fish, intermediate predatory fish, crustacean omnivores and mesoherbivores. Since the 1980 s, the commercial catch of gadoids on the Swedish west coast has decreased by $>90 \%$, and here we found that the biomass of top predators (gadoids and trout) that forage in seagrass has decreased by approximately $80 \%$. In contrast, the biomass of intermediate predatory fish (gobids and sticklebacks) has increased 8 times during summer and 11 times during autumn, while mesoherbivores (idoteids and gammarids $>7 \mathrm{~mm}$ ) have more or less disappeared from the seagrass bed. We thus found clear evidence that a shift in seagrass food web structure has taken place over the last 3 decades. Combining these findings with our recent empirical results from field cage experiments in the Skagerrak seagrass, where we manipulate top-down and bottom-up regulation, we conclude that lack of grazers in concert with eutrophication most likely contributed to the overgrowth by filamentous algae and disappearance of the seagrass on the Swedish west coast.
\end{abstract}

KEY WORDS: Food web structure $\cdot$ Overfishing $\cdot$ Eutrophication $\cdot$ Seagrass

\section{INTRODUCTION}

Seagrass meadows are globally widespread and recognised as productive and diverse coastal marine ecosystems. Seagrass habitats alter near-shore hydrodynamics, prevent coastal erosion and have invaluable connectivity to nearby habitats by providing food, shelter and nursery areas for migratory and stationary invertebrates and fish (reviewed by Orth et al. 2006, Rönnbäck et al. 2007, Duarte et al. 2008). Seagrasses are estimated to cover a minimum area of around $1.8 \times 10^{5} \mathrm{~km}^{2}$ worldwide (Green \& Short 2003), and the global economic value of ecosystem goods and services provided by seagrass/algae beds has been conservatively estimated to be double that of forests (Costanza et al. 1997). Human activities have altered seagrass ecosystems, with the worldwide distribution of seagrasses decreasing by $29 \%$ over the last $140 \mathrm{yr}$, and $58 \%$ of the remaining documented seagrass meadows is in decline (Waycott et al. 2009).

Zostera marina L. (eelgrass; hereafter Zostera) is a species of seagrass widely distributed along the Atlantic and Pacific coasts of the northern hemisphere extending into the Arctic, as well as the Baltic Sea 
(den Hartog 1970). The areal extent of Zostera along the Swedish west coast has declined by $60 \%$ since the mid-1980s (Baden et al. 2003). Although the distribution may vary inter-annually by about $\pm 5 \%$, a largescale long-term decline has been confirmed (Nyqvist et al. 2009). The most likely mechanisms responsible for the loss of Zostera are increased phytoplankton production, turbidity and overgrowth of epiphytic and filamentous ephemeral algae that out-compete the seagrasses for light and water column nutrients (McGlathery 1995, Hauxwell et al. 2001). In the early 1980 s, the coverage of filamentous algae in the Zostera meadows of the Swedish west coast was sparse (Baden \& Pihl 1984). During the past $25 \mathrm{yr}$, however, mats of filamentous algae dominated by Ulva species (syn. Enteromorpha) have increased in terms of both distribution and biomass in shallow coastal areas, including in Zostera beds along the Swedish west coast (Pihl et al. 1999, Jephson et al. 2008, Karlsson 2009). In addition, the decomposition of such algae leads to hypoxia and the production of hydrogen sulfide. The combination of low oxygen and intrusion of sulfide in seagrass is suggested as a key factor for sudden die-off (Holmer \& Bondgaard 2001, Borum et al. 2005). The sulfur content in seagrass may thus work as a biomarker of oxygen-stressed plants, and Holmer et al. (2009) found high sulfur contents in Zostera plants from the Swedish west coast.

A surplus of nutrients is often suggested as the main reason for increased primary production (eutrophication) leading to loss of seagrass (reviewed by Hauxwell et al. 2003). However, overfishing may also have an indirect effect on seagrass survival through the initiation of trophic cascades. When top predators are removed, intermediate and small predators increase in number and reduce the abundance of their main food items within the mesograzer group (e.g. small herbivorous amphipods, gastropods and harpacticoids), causing an easing of grazing pressure and a subsequent increase in nuisance algae (e.g. Heck et al. 2000, Jackson et al. 2001, Burkepile \& Hay 2006). Experiments have demonstrated that enhanced nutrient loading alone has little negative effect on seagrass growth when natural populations of mesoherbivores are present (Duffy \& Hay 2000, Hughes et al. 2004, Valentine \& Duffy 2006).

Recent correlative analyses have demonstrated that overfishing of top predators may have resulted in changes to food web structure in the Northwest Atlantic (Frank et al. 2005) and Baltic pelagic ecosystems (Harvey et al. 2003, Österblom et al. 2007, Casini et al. 2008), which may partly explain the general increase in primary production observed in these systems. Similar to the NW Atlantic and Baltic situations, large-scale declines in the abundance of top predatory gadoid species have also been documented on the Swedish west coast bordering the Skagerrak and Kattegat Sea, presumably as a result of overfishing (Svedäng \& Bardon 2003). In contrast to the documented overfishing of gadoid populations along the Swedish west coast, a stable population of mixed-sized cod is still present in the Öresund (the entrance to the Baltic), where no trawling has been allowed since the 1930s due to the dense commercial traffic (Lindegren et al. 2010, Svedäng 2010).

Concurrently, the nutrient load to Swedish coastal waters has increased 4 to 8 times since the 1930s and 2 to 3 times since the mid-1960s (Rosenberg et al. 1990, Boesch et al. 2008). The combined effect of these dramatic changes to the ecosystem has likely caused the observed increase in phytoplankton production and the decreased depth distribution of macroalgae (Rosenberg et al. 1990, Andersson \& Andersson 2006).

Trophic cascades in Zostera meadows have been investigated empirically on the Swedish west coast by cage experiments simultaneously manipulating levels of nutrients, predators and grazers. These experiments showed that an increased level of nutrients in concert with added intermediate predators resulted in a decreased abundance of grazers, increased bloom of filamentous algae and decreased growth of seagrass (Moksnes et al. 2008, Baden et al. 2010). Thus, processes that have caused changes to food web structure can be partly responsible for the overgrowth of seagrass by filamentous algae and subsequent extensive seagrass loss on the Swedish west coast.

Correlative and empirical studies provide a good indication of possible scenarios taking place in seagrass ecosystems, but is still a great demand for data that enable a historical comparison of events at different trophic levels. Here we compared quantitative data of 4 feeding guilds: top predatory fish, intermediate predatory fish, crustacean omnivores and mesoherbivores ( $>7 \mathrm{~mm}$ ), in Zostera meadows on the Swedish west coast sampled during the 1980s and 2000s. We hypothesised that overfishing of top predators (mainly gadoids) led to an increased dominance of intermediate predators (small fish and crustaceans) that has itself reduced mesoherbivore density in Zostera ecosystems of the Skagerrak. To fortify this hypothesis, we would expect to find fewer intermediate predators and more mesoherbivores in the less disturbed Öresund region where top predators are still abundant. 
Table 1. Studies included in the historical comparison for each feeding guild of Zostera marina, showing sampling year, season (S: summer, A: autumn), sampling method (GN: gill net, DT: drop trap, BS: beach seine, DB: diving bag) and location (A-I are 9 different sites located on the Swedish NW coast; $\mathrm{J}$ is in the Öresund)

\begin{tabular}{|c|c|c|c|c|c|c|}
\hline Trophic group & Year & Season & $\begin{array}{l}\text { Sampling } \\
\text { method }\end{array}$ & Location & $\begin{array}{l}\text { No. replicates } \\
\text { per sampling } \\
\text { and location }\end{array}$ & Source \\
\hline \multirow[t]{6}{*}{ Top predatory fishes } & 1979 & $\mathrm{~A}$ & GN & $\mathrm{F}$ & 1 & Pihl (1982) \\
\hline & 1980 & $\mathrm{~S}$ & GN & $\mathrm{F}$ & 2 & Pihl (1982) \\
\hline & 1980 & $\mathrm{~A}, \mathrm{~A}$ & GN & $\mathrm{F}$ & 3 & Pihl (1982) \\
\hline & 2000 & $\mathrm{~A}$ & GN & $\mathrm{F}$ & 1 & L. Pihl unpubl. \\
\hline & 2001 & $\mathrm{~A}$ & GN & $\mathrm{F}$ & 1 & L. Pihl unpubl. \\
\hline & 2002 & $\mathrm{~A}$ & GN & $\mathrm{F}$ & 1 & L. Pihl unpubl. \\
\hline \multirow{11}{*}{$\begin{array}{l}\text { Intermediate predatory } \\
\text { fishes }\end{array}$} & 1982 & $\mathrm{~S}, \mathrm{~A}$ & DT & $\mathrm{A}, \mathrm{B}, \mathrm{C}$ & 10 & Baden \& Pihl (1984) \\
\hline & 1985 & A & DT & $\mathrm{B}$ & 5 & S. Baden \& L. Pihl unpubl. \\
\hline & 1988 & $\mathrm{~S}, \mathrm{~A}$ & DT & $\mathrm{A}, \mathrm{B}$ & 10 & L. Pihl unpubl. \\
\hline & 1990 & $\mathrm{~S}, \mathrm{~A}$ & DT & $\mathrm{A}, \mathrm{B}$ & 10 & L. Pihl unpubl. \\
\hline & 2001 & A & $\mathrm{BS}$ & $\mathrm{A}, \mathrm{D}, \mathrm{E}, \mathrm{G}, \mathrm{H}, \mathrm{I}$ & 1 & L. Pihl et al. unpubl. \\
\hline & 2004 & $\mathrm{~S}$ & $\mathrm{BS}$ & $\mathrm{A}, \mathrm{B}, \mathrm{C}$ & 2 & Pihl et al. (2006) \\
\hline & 2008 & $\mathrm{~S}$ & DT & $\mathrm{B}, \mathrm{D}$ & 10 & Present study \\
\hline & 2008 & $\mathrm{~A}$ & DT & $\mathrm{B}$ & 10 & Present study \\
\hline & 2008 & $\mathrm{~S}$ & BS & $\mathrm{B}, \mathrm{D}$ & 2 & Present study \\
\hline & 2008 & $\mathrm{~A}$ & $\mathrm{BS}$ & $\mathrm{B}$ & 2 & Present study \\
\hline & 2008 & $\mathrm{~S}$ & BS & $\mathrm{J}$ & 2 & Present study \\
\hline \multirow[t]{7}{*}{ Omnivore crustaceans } & 1982 & $\mathrm{~S}, \mathrm{~A}$ & DT & $\mathrm{A}, \mathrm{B}, \mathrm{C}$ & 10 & Baden \& Pihl (1984) \\
\hline & 1985 & A & DT & B & 5 & S. Baden \& L. Pihl unpubl. \\
\hline & 1988 & $\mathrm{~S}, \mathrm{~A}$ & DT & $\mathrm{A}, \mathrm{B}$ & 10 & L. Pihl unpubl. \\
\hline & 1990 & $\mathrm{~S}, \mathrm{~A}$ & DT & $\mathrm{A}, \mathrm{B}$ & 10 & L. Pihl unpubl. \\
\hline & 2004 & A & $\mathrm{DB}$ & $\mathrm{B}, \mathrm{D}$ & 6 & Jephson et al. (2008) \\
\hline & 2008 & $\mathrm{~S}$ & DT & $\mathrm{B}, \mathrm{E}$ & 10 & Present study \\
\hline & 2008 & $\mathrm{~A}$ & DT & $\mathrm{B}$ & 10 & Present study \\
\hline Mesoherbivores & 1982 & $\mathrm{~S}, \mathrm{~A}$ & DT & $\mathrm{A}, \mathrm{B}, \mathrm{C}$ & 10 & Baden \& Pihl (1984) \\
\hline \multirow[t]{2}{*}{ (idoteids) } & 1985 & $\mathrm{~A}$ & DT & $\mathrm{B}$ & 5 & S. Baden \& L. Pihl unpubl. \\
\hline & 1988 & $\mathrm{~S}, \mathrm{~A}$ & $\mathrm{DB}$ & $\mathrm{A}, \mathrm{B}$ & 10 & L. Pihl unpubl. \\
\hline Mesoherbivores & 1985 & $\mathrm{~S}$ & DB & $\mathrm{C}$ & 5 & S. Baden \& L. Pihl unpubl. \\
\hline \multirow[t]{2}{*}{ (gammarids) } & 1986 & $\mathrm{~S}$ & DB & $\mathrm{A}, \mathrm{C}$ & 10 & Baden (1990, unpubl.) \\
\hline & 1986 & $\mathrm{~A}$ & $\mathrm{DB}$ & $\mathrm{C}$ & 10 & Baden (1990, unpubl.) \\
\hline Mesoherbivores & 1997 & $\mathrm{~S}$ & $\mathrm{DB}$ & $\mathrm{B}, \mathrm{C}, \mathrm{E}$ & 6 & S. Baden \& L. Gerhardt unpubl. \\
\hline \multirow{3}{*}{ (idoteids \& gammarids) } & 2004 & $\mathrm{~A}$ & $\mathrm{DB}$ & $\mathrm{B}, \mathrm{D}$ & 5 & Baden et al. (2010, unpubl.) \\
\hline & 2008 & $\mathrm{~S}, \mathrm{~A}$ & $\mathrm{DB}$ & $\mathrm{B}, \mathrm{E}$ & 10 & Present study \\
\hline & 2008 & $\mathrm{~S}$ & DB & $\mathrm{J}$ & 6 & Present study \\
\hline
\end{tabular}

\section{MATERIALS AND METHODS}

\section{Study area}

The investigation was carried out in Zostera marina meadows of 1 to 2 ha in size and water depth of 1 to $2.5 \mathrm{~m}$ in the outer part of Gullmarsfjord, Koljöfjord and Brofjord on the Swedish northwest coast $\left(\sim 58^{\circ} 14^{\prime} \mathrm{N}, 11^{\circ} 24^{\prime} \mathrm{E}\right)$ within a $30 \times 30 \mathrm{~km}$ area. Zostera appears in May, and all leaves disappear in winter. The area has a tidal range of $0.2 \mathrm{~m}$. Water temperatures vary from 10 to $15^{\circ} \mathrm{C}$ in spring and autumn and are around $20^{\circ} \mathrm{C}$ in summer. Surface salinity varies between 15 and $25 \mathrm{ppt}$, and the sediment is muddy (for details see Baden \& Pihl 1984, Jephson et al. 2008).

\section{Study period and method}

All samplings used for this historic comparison were carried out under the supervision of 2 of the authors (S. Baden and L. Pihl), minimising variance in use of equipment (Table 1). Quantitative (drop trap and bag trap) and semi-quantitative (gill net and beach seine) samples of top predatory fish, intermediate predatory fish, crustacean omnivores and mesoherbivores were taken in Zostera meadows in June/July (hereafter 'summer') and September/October (hereafter 'autumn'). Samples were collected during the periods 1979 to 1990 (hereafter '1980s') and 2000 to 2008 (hereafter '2000s'), and the data were analysed for temporal trends (see Tables 1 \& 2). In 2008, quantitative diving bag and semi-quantitative 
(beach seine) samples were also collected in 2 Zostera meadows in the Öresund region of southern Sweden (555 $53^{\prime} \mathrm{N}, 12^{\circ} 42^{\prime} \mathrm{E}$; Table 1 ).

Abundance and biomass data are presented for predatory fish as catch per effort per night for 2 ha, and as individuals and weight per $\mathrm{m}^{2}$ for intermediate predatory fish, crustacean omnivores and mesoherbivores. Biomass is given as $\mathrm{g}$ wet weight (wet wt) for all groups. Some historical data were originally reported as dry weight or ash-free dry weight and were therefore converted into wet wt using calibration factors taken from Baden \& Pihl (1984), Rumohr et al. (1987), and Baden (1990).

\section{Sampling gear}

The gill net (GN) used for sampling top predatory fish was a monofilament survey net (36 m long, $1.5 \mathrm{~m}$ high) containing 12 different mesh sizes ( $3 \mathrm{~m}$ sections of meshes ranging from 6.25 to $75 \mathrm{~mm}$ randomly distributed in each net; Pihl 1982, Nyberg \& Degerman 1988). On each sampling occasion, 5 nets were used, with fishing taking place in calm weather and overnight (8 h) in Zostera meadows at $1.5 \mathrm{~m}$ depth. After capture, all fish were enumerated, measured and weighed in the field.

The beach seine (BS) used for sampling intermediate predatory fish was $40 \mathrm{~m}$ long, $3.7 \mathrm{~m}$ high and had a mesh size of $10 \mathrm{~mm}$ (stretched mesh size $15 \mathrm{~mm}$ ) in the arms and $5 \mathrm{~mm}$ in the central section. The BS prototype was constructed in Norway for semi-quantitative sampling of intermediate predators larger than about $40 \mathrm{~mm}$ and has been used in more than 250 locations on the southern Norwegian coast on a yearly basis since 1919 (Johannesson \& Sollie 1994). The BS was launched from a small motorboat reversing in a semi-circle while the net was unfolded into the water. The seine was then towed by two $30 \mathrm{~m}$ ropes to the shore, and followed by a snorkeler who ensured that the seine followed the seabed. On the shore, fish were sorted, counted and released. Before release, a subsample of about 20 individuals of the dominant species was placed on ice before being deep-frozen at the end of the day. In the laboratory, length and weight were analysed, and during 2008, we also investigated the food choice of 3 intermediate predatory fish species. The effective coverage area was estimated to be around $300 \pm 50 \mathrm{~m}^{2}$, with this figure calculated as the seine, approximated as a semi-circle, plus the pull area in the Zostera meadows. In this study, the additive pull area was relatively small, but can be made larger to cover greater areas of Zostera meadows (e.g. $500 \mathrm{~m}^{2}$ in Pihl et al. 2006)

A drop trap (DT) is considered to be a high-precision quantitative method for sampling of mobile epifauna, including intermediate predators, omnivore crustaceans and mesoherbivores larger than about 10 mm (Pihl \& Rosenberg 1982, Baden \& Pihl 1984). In each meadow, around 10 random samples were taken using a $1.5 \mathrm{~m}$ high open DT with a base area of $0.5 \mathrm{~m}^{2}$. The trap consists of an aluminium frame with a $1 \mathrm{~mm}$ mesh nylon net inserted into the upper metre of each side. The DT was released from a boat and the animals recovered with a $1 \mathrm{~mm}$ mesh hand net fixed to a $3 \mathrm{~m}$ handle (Baden \& Pihl 1984).

The bag trap (BT) encloses all herbivores $>0.2 \mathrm{~mm}$ including invertebrate omnivores of 30 to $40 \mathrm{~mm}$ but is not an appropriate gear for fast-swimming fish. The BT was used by divers and was composed of a bag (mesh size $0.2 \mathrm{~mm}$, height $1.0 \mathrm{~m}$ ) with a quadratic steel frame measuring $0.12 \mathrm{~m}^{2}(0.35 \times 0.35 \mathrm{~m})$ forming the opening. The trap was carefully lowered over the Zostera and the shoots cut at the bottom. Six to 10 samples were taken randomly in each bed, immediately put on ice and later frozen before undergoing analysis in the laboratory. The bag sampling method is considered quantitative and suitable for herbivores >0.2 mm (Baden 1990, Jephson et al. 2008, S. Baden et al. unpubl. data).

During the 1980s, gammarid and idoteid crustaceans were not consequently sampled simultaneously. Means of gammarid and idoteid abundance and biomass were therefore summed and used as total mesoherbivore measurements (Fig. 1). Hence these samples were not used in statistical comparative analyses (Table 2).

\section{Correlation between DT and BS}

Intermediate fish predators were caught by DT during the 1980s and BS during the 2000s. To be able to accurately compare the results of early DT sampling (1982, 1988 and 1990) with later BS sampling (2001, 2004 and 2008), a simultaneous comparison of these 2 methods was carried out in 2 Zostera meadows on 3 occasions between June and October of 2008. On each occasion, 2 BS and 10 DT samples were taken in each meadow. Gear inter-calibration factors between BS and DT samples were calculated for all shared species by normalising both DT and BS data to abundance per $\mathrm{m}^{2}$ and calculating the ratio (DT:BS) in terms of sampled species density for the 2 methodologies. The results of this comparison 
showed that DTs were more efficient for sampling crab (at densities 2 orders of magnitude higher compared to BS), shrimp (densities 1 order of magnitude higher compared to BS) and fish species (densities in the same order of magnitude but about 3 times higher compared to BS). The difference in sampling efficiency between the gears depends mainly on the size and behaviour of animals. For instance, many
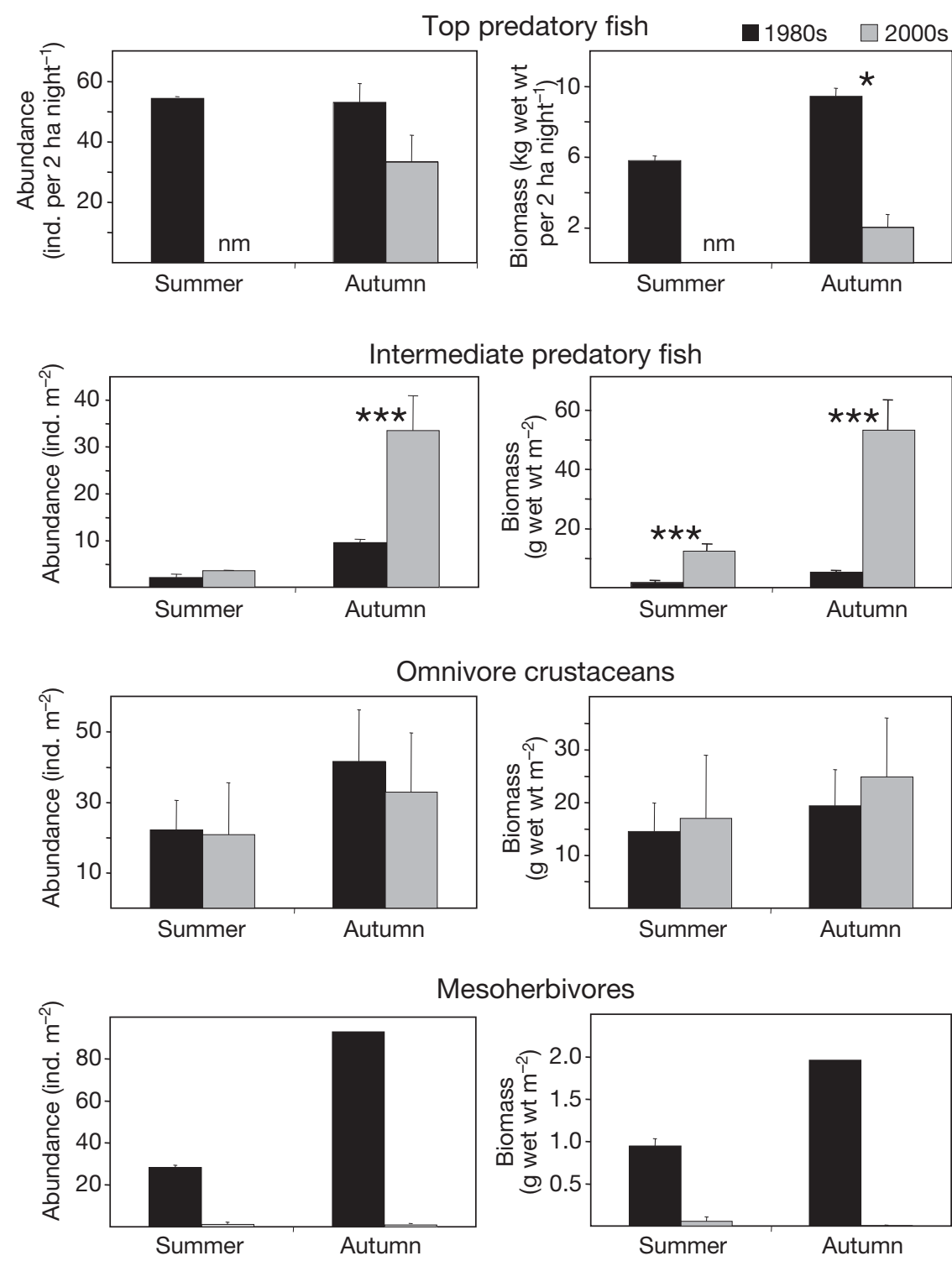

Mesoherbivores

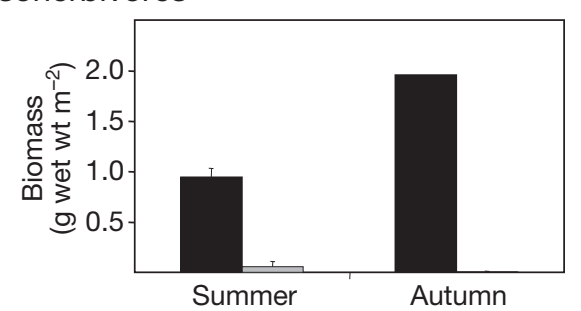

Fig. 1. Mean + SE abundance and biomass of feeding guilds in Zostera marina meadows on the Swedish NW coast: top predatory fish, intermediate predatory fish, crustacean omnivores and crustacean mesoherbivores in summer (June-July) and autumn (September-October) during the 1980s (black) and 2000s (grey). Abundance for all trophic levels (ind. $\mathrm{m}^{-2}$ ), except top predatory fish (ind. per 2 ha per night). Biomass for all trophic levels (g wet weight, wet $\mathrm{wt}, \mathrm{m}^{-2}$ ), except top predatory fish (kg wet wt per 2 ha per night). Levels of significance: ${ }^{*} \mathrm{p}<0.05,{ }^{* * *} \mathrm{p}<0.001 ; \mathrm{nm}$ : not measured crustaceans may be small in size and pass through the BS meshes. Other species may be more closely associated with the seagrass or the seabed and therefore less prone to be caught in the BS samples. As a result, a calibration factor was only used for temporal comparison of the abundance and biomass of interediate predatory fish. Including all 16 fish species found in DT and/or BS samplings, the mean calibration factor (CF) for DT:BS was 3.5 (SE $0.74, \mathrm{n}=3$ ). All existing data for intermediate fish predators sampled using BS (calibrated with the factor 3.5) and DT were used in the present study.

Comparative studies of the different fishing gear used in marine and freshwater habitats were reviewed by Beesley \& Gilmour (2008). Studies comparing drop or pop nets and BS in macrophytes were carried out by Connolly (1994) in an Australian Zostera meadow (0.4-1 $\mathrm{m}$ depth) and by Beesley \& Gilmour (2008) in several limnic habitats, of which a vegetated pool (0.9-1.3 $\mathrm{m}$ depth) is the one that most resembles a marine seagrass meadow. Every documented comparison is unique in terms of the surface area of traps, length and mesh sizes of BSs as well as the behaviour of fish fauna in different habitats. In spite of this, CFs for the abundance of intermediate predatory fish sampled in DTs and BSs were found to be 2.27 and 3.9 in the studies of Beesley \& Gilmour (2008) and Connolly (1994), respectively. Thus, the CF of 3.5 used in the present study is in agreement with these previous findings.

\section{Historical comparison statistics}

Temporal differences in animal abundance and biomass over 3 decades on the Swedish NW coast were analysed for each of the feeding guilds: top predatory fish, intermediate predatory fish, crustacean omnivores and mesoherbivores. In addition, temporal differences were also analysed for dominant species, which on all occasions made up $90 \%$ of the fauna within each guild. 
Table 2. Statistical results of changes within each feeding guild of Zostera marina fauna between the 1980s and 2000s on the Swedish NW coast. A (a) $t$-test was used when data satisfied normality and, in the other cases, a (b) Mann-Whitney rank sum test was performed. A: abundance, B: biomass. (See Fig. 2 for Latin names.) Values in bold are significant at $\mathrm{p}<0.05$

\begin{tabular}{|c|c|c|c|c|c|}
\hline \multirow{2}{*}{ (a) Trophic group } & \multirow{2}{*}{ Season } & \multirow{2}{*}{ Selected species } & \multicolumn{3}{|c|}{$-t$-test } \\
\hline & & & df & $t$ & $\mathrm{p}$ \\
\hline \multirow[t]{6}{*}{ Top predatory fishes } & \multirow[t]{6}{*}{ Autumn } & Total top pred. A & 4 & 1.862 & 0.136 \\
\hline & & Total top pred. B & 4 & 3.102 & 0.036 \\
\hline & & $\operatorname{Cod} \mathrm{A}$ & 4 & 5.181 & 0.007 \\
\hline & & Cod B & 4 & 4.374 & $0.01^{a}$ \\
\hline & & Trout A & 4 & -1.519 & 0.204 \\
\hline & & Trout B & 4 & -0.873 & 0.432 \\
\hline \multirow[t]{2}{*}{ (b) Trophic group } & \multirow[t]{2}{*}{ Season } & \multirow[t]{2}{*}{ Selected species } & \multicolumn{3}{|c|}{ — Mann-Whitney rank sum test } \\
\hline & & & $\begin{array}{c}\mathrm{n} \\
(1980,2000)\end{array}$ & $t$ & $\mathrm{p}$ \\
\hline \multirow{15}{*}{$\begin{array}{l}\text { Intermediate predatory } \\
\text { fishes }\end{array}$} & \multirow[t]{7}{*}{ Summer } & Total intermed. pred. A & 7,7 & 43 & 0.259 \\
\hline & & Total intermed. pred. B & 7,7 & 29 & $<0.001$ \\
\hline & & Black goby A \& B & 7,7 & 37 & 0.053 \\
\hline & & Three-spined stickleback A \& B & 7,7 & 41 & 0.165 \\
\hline & & Two-spotted goby A \& B & 7,7 & 41 & 0.165 \\
\hline & & Nine-spined stickleback A \& B & 7,7 & 69 & 0.038 \\
\hline & & Pipefish A \& B & 7,7 & 52 & 1.000 \\
\hline & \multirow[t]{8}{*}{ Autumn } & Total intermed. pred. A & 7,7 & 76 & 0.001 \\
\hline & & Total intermed. pred. B & 7,7 & 77 & $<0.001$ \\
\hline & & Black goby A \& B & 7,7 & 61 & 0.318 \\
\hline & & Nine-spined stickleback A \& B & 7,7 & 70 & 0.026 \\
\hline & & Three-spined stickleback A \& B & 7,7 & 71 & 0.017 \\
\hline & & Two-spotted goby A \& B & 7,7 & 31 & 0.004 \\
\hline & & Pipefish A & 7,7 & 61 & 0.318 \\
\hline & & Pipefish B & 7,7 & 60 & 0.383 \\
\hline \multirow[t]{11}{*}{ Omnivore crustaceans } & \multirow[t]{5}{*}{ Summer } & Total omnivore crust. A & 7,2 & 11 & 0.889 \\
\hline & & Total omnivore crust. B & 7,2 & 13 & 0.500 \\
\hline & & Palaemon spp. A \& B & 7,2 & 14 & 0.333 \\
\hline & & Carcinus A & 7,2 & 5 & 0.222 \\
\hline & & Carcinus B & 7,2 & 12 & 0.667 \\
\hline & \multirow[t]{6}{*}{ Autumn } & Total omnivore crust. A & 8,3 & 15 & 0.630 \\
\hline & & Total omnivore crust. B & 8,3 & 20 & 0.776 \\
\hline & & Palaemon spp. A & 8,3 & 15 & 0.630 \\
\hline & & Palaemon spp. B & 8,3 & 16 & 0.776 \\
\hline & & Carcinus A & 8,3 & 12 & 0.279 \\
\hline & & Carcinus B & 8,3 & 13 & 0.376 \\
\hline \multirow[t]{7}{*}{ Mesoherbivores } & \multirow[t]{4}{*}{ Summer } & Total mesoherbivores A \& B & 2,2 & 7 & 0.330 \\
\hline & & Idoteids A & 5,5 & 17 & 0.032 \\
\hline & & Idoteids B & 5,5 & 38 & 0.032 \\
\hline & & Gammarids A \&B & 3,5 & 21 & 0.036 \\
\hline & \multirow[t]{3}{*}{ Autumn } & Total mesoherbivores A \& B & 1,4 & Not possible & \\
\hline & & Idoteids A \& B & 4,5 & 10 & 0.016 \\
\hline & & Gammarids A \& B & 1,4 & Not possible & \\
\hline
\end{tabular}

Mean abundance and biomass of the analysed feeding guilds and species during the 2 decades (1980s and 2000s) and 2 seasons (summer and autumn) are depicted in Figs. 1 \& 2. Temporal differences in abundance and biomass of the total species and of selected species in each feeding guild were tested using a $t$-test. To achieve equal variances, a square-root transformation was used. When the data failed tests for normality (Shapiro-Wilk) due to the frequent occurrence of 0 abundance and biomass observations, a Mann-Whitney $U$-test was used (Table 2). 
Top predatory fish

1980s $\square$ 2000s
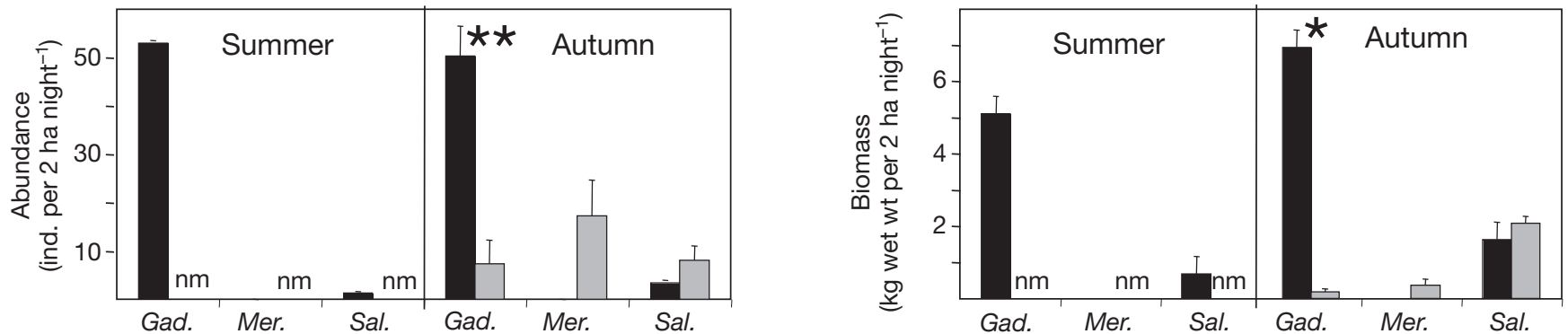

Intermediate predatory fish
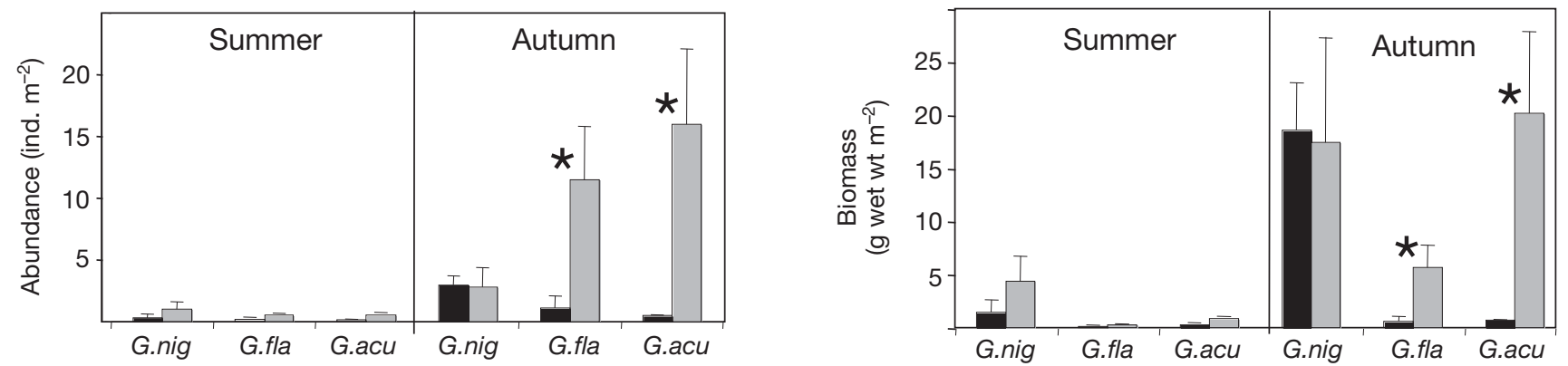

Omnivore crustaceans
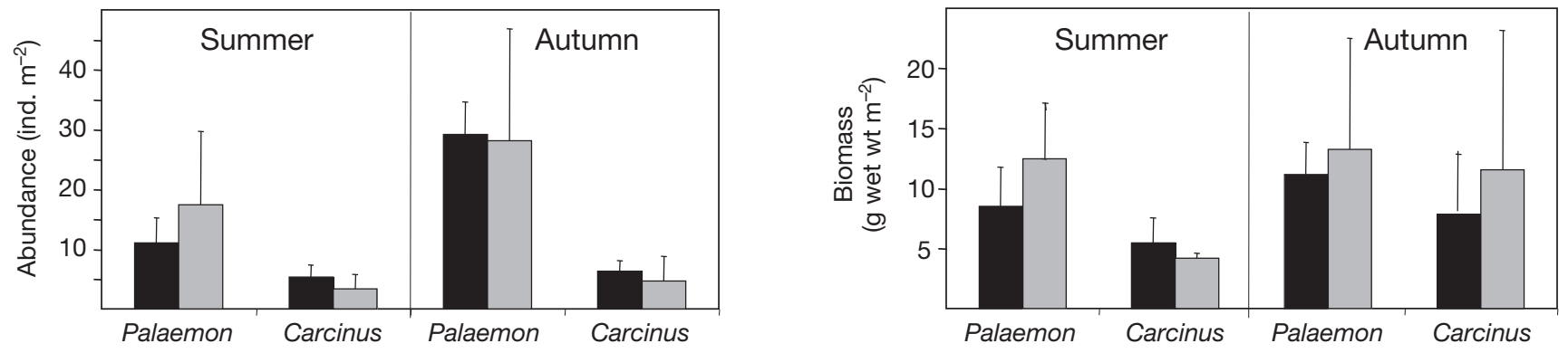

Mesoherbivores
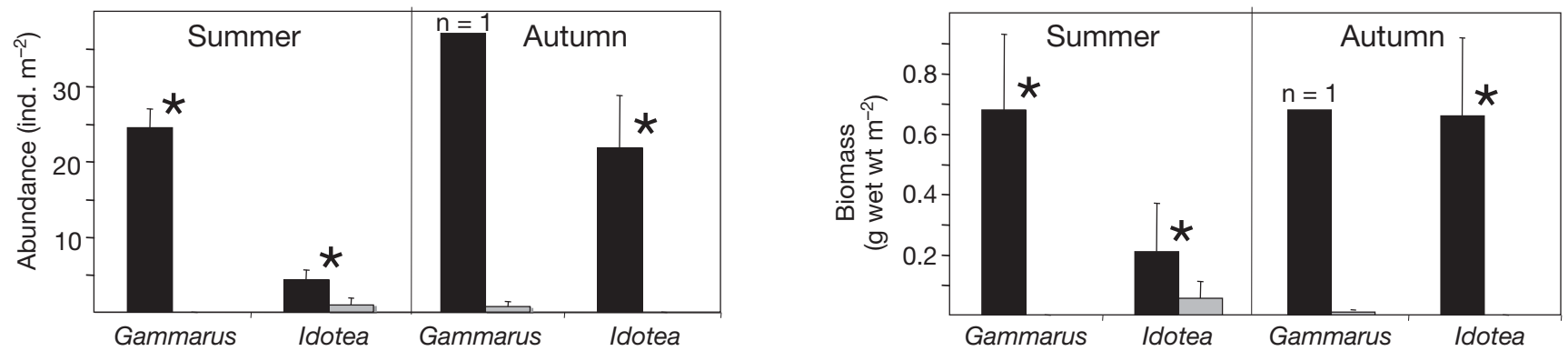

Fig. 2. Mean + SE abundance and biomass (same units as in Fig. 1) of the dominant species in each feeding guild from the Swedish north west coast Zostera marina habitat: top predatory fish, intermediate predatory fish, crustacean omnivores and mesoherbivores in summer (June-July) and autumn (September-October) during the 1980s (black) and 2000s (grey). Gad.: Gadus morhua (cod), Mer.: Merlangius merlangus (whiting) and Sal.: Salmo trutta (trout), G.nig: Gobius niger (black goby), G.fla: Gobiusculus flavescens (two-spotted goby), G.acu: Gasterosteus aculeatus (three-spined stickleback), Palaemon: Palaemon spp. (grass shrimps), Carcinus: Carcinus maenas (green crab), Gammarus: Gammarus spp. and Idotea: Idotea spp. 


\section{RESULTS}

The dominant species of top predatory fish visiting Zostera meadows and feeding on prey associated with Zostera were mainly cod Gadus morhua, whiting Merlangius merlangus and trout Salmo trutta. During the 1980s, the mean wet wt and length of cod sampled in June were $96 \mathrm{~g}$ and $220 \mathrm{~mm}$, increasing to $214 \mathrm{~g}$ and $290 \mathrm{~mm}$ in October. From the 2000s, only samples from October were available, with mean cod wet wt of only $25 \mathrm{~g}$ and corresponding length of $145 \mathrm{~mm}$. The sampled trout increased in wet wt from 523 to $652 \mathrm{~g}$ and in length from 341 to $373 \mathrm{~mm}$ between summer and autumn in the 1980s. The autumn 2000s trout mean wet wt and length were $185 \mathrm{~g}$ and $267 \mathrm{~mm}$.

Overall, the assemblage of predatory fish showed a significant decrease in autumn biomass and a weakly negative decrease in abundance $(p=0.136)$ over the study period (Table 2, Fig. 1). Abundance and biomass of cod decreased by 85 and $97 \%$, respectively (Table 2, Fig. 2). In contrast at the same time, smallsized whiting $(22 \mathrm{~g}$ wet $\mathrm{wt}, 145 \mathrm{~mm})$ that were not present in the 1980s appeared in relatively high numbers in catches taken from 2000 to 2002. Trout abundance showed a weakly positive effect $(p=0.204)$ over the study period, but not in biomass, since mean individual weight had decreased over the same period (Table 2, Fig. 2).

The intermediate predatory fish were dominated by black goby Gobius niger, two-spotted goby Gobiusculus flavescens and three-spined stickleback Gasterosteus aculeatus. No difference was found in individual weight and length of the sampled intermediate predators between decades. Between summer and autumn, 2 species increased in mean wet wt and length: black goby from $3.4 \mathrm{~g}$ and $65 \mathrm{~mm}$ to $6.2 \mathrm{~g}$ and $73 \mathrm{~mm}$, and three-spined stickleback from $1.0 \mathrm{~g}$ and $7 \mathrm{~mm}$ to $1.3 \mathrm{~g}$ and $46 \mathrm{~mm}_{\text {; }}$ in contrast, two-spotted goby remained unchanged at $0.5 \mathrm{~g}$ and $41 \mathrm{~mm}$. Food choice analysis of these 3 species showed that black goby $(40-90 \mathrm{~mm}, \mathrm{n}=22)$ fed on amphipods of mesoherbivore size between 300 and $600 \mu \mathrm{m}$, while twospotted goby (35-45 mm, $\mathrm{n}=19)$ fed on meiofaunal ostracods $(40-50 \mu \mathrm{m})$, harpacticoids $(30-100 \mu \mathrm{m})$ and gastropods $(20-50 \mu \mathrm{m})$, with the addition of some Culicidae (mosquito larvae, 300-1000 $\mu \mathrm{m}$ ) and amphipods $(300-500 \mu \mathrm{m})$. Three-spined stickleback $(20-$ $70 \mathrm{~mm}, \mathrm{n}=18)$ fed on chironomid larvae (300$500 \mu \mathrm{m})$, harpacticoids $(100 \mu \mathrm{m})$ and small amphipods $(150-400 \mu \mathrm{m})$. Less abundant intermediate predatory fish included in total abundance and biomass of Fig. 1 were nine-spined stickleback Pungitius pungitius and deep-snouted pipefish Syngnathus typhle.
The intermediate predatory fish species were sampled by DT during the 1980s and by BS during the 2000s. As described in the 'Materials and methods', we found that the DT was 3.5 times more efficient than the BS. When using this gear $\mathrm{CF}_{\text {, we found that }}$ the total biomass ( $g$ wet $\mathrm{wt} \mathrm{m}^{-2}$ ) of intermediate predatory fish had increased significantly by a factor 8 in summer and a factor of 11 in autumn between the 1980 and 2000 sampling. Abundance had increased significantly only during autumn and by a factor of 3 (Table 2, Fig 1). To show that results were robust to changes in the gear $\mathrm{CF}$, the observed increase in summer and autumn biomass of intermediate predatory fish remained significant even if the DT:BS CF was reduced to 1.5 for the summer and 1 for the autumn biomass. The increase in total biomass of intermediate predatory fish was mainly caused by a weakly positive increase for black goby $(p=0.053)$ and three-spined stickleback $(p=0.165)$ during summer and a significant increase in biomass of both the schooling two-spotted goby and threespined stickleback in autumn (Table 2, Fig. 2). Pipefish had unchanged mean abundance $\left(0.2\right.$ ind. $\mathrm{m}^{-2}$ in summer and 2 ind. $\mathrm{m}^{-2}$ in autumn) and biomass (0.5 in summer and $8 \mathrm{~g}$ wet wt $\mathrm{m}^{-2}$ in autumn), while the nine-spined stickleback ( 0.6 ind. $\mathrm{m}^{-2}$ in summer and 1.7 ind. $\mathrm{m}^{-2}$ in autumn and corresponding wet wt of 0.84 and $2.16 \mathrm{~g} \mathrm{~m}^{-2}$ in the 1980s) almost disappeared from the studied Zostera meadows between the 1980s and 2000s.

Crustacean omnivores included the 2 similar sized grass shrimps Palaemon adpersus and P. elegans and the green crab Carcinus maenas. Both Palaemon spp. and $C$. maenas had about the same individual mean size in the 1980s and 2000s. The Palaemon spp. decreased in mean wet wt and length between summer and autumn due to recruitment (see Baden \& Pihl 1984) from $0.8 \mathrm{~g}$ and $33 \mathrm{~mm}$ to $0.4 \mathrm{~g}$ and $26 \mathrm{~mm}$. C. maenas in Zostera meadows is dominated by 1group individuals with some 2-group individuals in summer and recruitment of 0-group individuals in autumn (Baden \& Pihl 1984). The mean wet wt and maximum carapace width increased between summer and autumn from $1.2 \mathrm{~g}$ and $19 \mathrm{~mm}$ to $2.5 \mathrm{~g}$ and $22 \mathrm{~mm}$ due to growth (Baden \& Pihl 1984). No longterm changes were observed in abundance and biomass of grass shrimps or green crabs (Figs. 1 \& 2, Table 2). However, a shift in dominance between the 2 species of grass shrimp was observed, with the contribution of $P$. elegans to total shrimp abundance increasing from 3 to $32 \%$ from the 1980 s to the 2000 s.

The mesoherbivores (>7 mm as adults) were Gammarus spp. (mainly G. locusta) and Idotea spp. (mainly 
I. balthica). With exception of the 5 I. balthica individuals found in summer 2008 which had a mean wet wt of $0.1 \mathrm{~g}$ and length of $21 \mathrm{~mm}$, only specimens from the 1980s are documented. Between summer and autumn, Gammarus sp. decreased in mean wet wt and length from $0.03 \mathrm{~g}$ and $8.5 \mathrm{~mm}$ to $0.02 \mathrm{~g}$ and $7.5 \mathrm{~mm}$, and I. balthica from $0.05 \mathrm{~g}$ and $15 \mathrm{~mm}$ to $0.03 \mathrm{~g}$ and $13 \mathrm{~mm}$ due to recruitment (Baden \& Pihl 1984).

Gammarids and idoteids were only sampled simultaneously twice during the summers in the 1980s and once during the autumn in the 1980s. Thus, statistical analysis is only possible on the mesoherbivores when separated into gammarids and idoteids. Summer abundance and biomass of both gammarids and idoteids decreased significantly between the 1980s and 2000s (Table 2, Fig. 2). During the autumn, idoteids decreased significantly in both abundance and biomass (Table2, Fig. 2). As only one autumn sampling including gammarids was carried out during the 1980s, a statistical analysis of gammarids was not possible.

In the reference area of Öresund (2 meadows), current intermediate fish abundance and biomass (mean \pm SE) levels in summer were $1.4 \pm 0.07$ ind. $\mathrm{m}^{-2}$ and $1.79 \pm 0.25 \mathrm{~g}$ wet $\mathrm{wt} \mathrm{m}^{-2}$, respectively. These values are lower than those of the Skagerrak Zostera meadows during the 1980s. The current abundance and biomass (mean $\pm \mathrm{SE}$ ) of adult $(>7 \mathrm{~mm})$ mesoherbivores in an Öresund meadow (dominated by Idotea spp. but including some Gammarus spp.) was $32.7 \pm$ 7.0 ind. $\mathrm{m}^{-2}$ and $1.06 \pm 0.22 \mathrm{~g}$ wet $\mathrm{wt} \mathrm{m}^{-2}$, respectively, which are close to values recorded for the Skagerrak Zostera habitats in the 1980s.

\section{DISCUSSION}

Quantitative changes within functional food web groups were observed in Zostera meadows on the Swedish west coast between the 1980s and 2000s. Results suggest that the decline in top predatory fish, exemplified by the dramatic reduction in commercial catch along the whole of the Swedish west coast (Svedäng \& Bardon 2003, Svedäng 2010) as well as lowered abundance of locally foraging younger age groups (present study), has led to a simultaneous increase in intermediate predatory fish and a reduction of mesoherbivores. These changes in concert with nutrient enrichment are likely to explain the overgrowth of filamentous algae in Zostera beds. Our findings thus support the conclusions drawn from field caging experiments in Zostera meadows which showed that the difference in predation pressure caused by intermediate predatory fish may cascade down and affect the composition and abundance of mesoherbivores (small crustaceans and gastropods), which in turn influence the biomass of filamentous algae (Moksnes et al. 2008, Baden et al. 2010). Depending on the number of trophic levels and complexity of the food web, this cascade can be either synergistic or antagonistic to documented eutrophication (Oksanen et al. 1981, Rosenberg et al. 1990, Diaz \& Rosenberg 2008, Moksnes et al. 2008, Eriksson et al. 2009, Baden et al. 2010).

Overfishing of cod in the Kattegat and Skagerrak along the Swedish west coast has caused a stock decrease of over $90 \%$ since the early 1970 s, with the most dramatic decline occurring from the mid-1980s (Svedäng \& Bardon 2003). Cod was therefore still relatively abundant when the first sampling of organisms in this study was carried out (Pihl 1982). It is highly likely that the continuous excessive fishing, taking place during the last 2 decades, explains the dramatic drop in juvenile cod abundance and biomass in these seagrass habitats between the 1980s and 2000s (Fig. 2). This is confirmed by coastal trawl surveys in fjords of the Skagerrak archipelago during the 2000s that reveal strongly decimated cod populations compared to previous sampling in the $1970 \mathrm{~s}$ (Svedäng \& Svenson, 2006).

In the 1980s, high densities of 1- and 2-group cod were found in the Zostera meadows, whereas in the 2000 s, only a few of the 0 -group were recorded. The concomitant appearance of small whiting as the cod disappeared may be a consequence of the reduction in predation pressure and/or interspecific competition for food in juveniles, as suggested by Hop et al. (1994). The increasing numbers of trout observed in recent catches may also be due to its reduced interaction with cod in the seagrass meadows. Stomach analyses from fish surveys (L. Pihl unpubl. data) show that cod and trout share common food items, e.g. Nereidae, Crangon crangon, Pomatoschistus spp. and Sprattus sprattus, suggesting a significant diet overlap between the 2 species.

The 8- to 11-fold increase in biomass of intermediate predatory fish in Zostera meadows over the last 3 decades is driven by the increased biomass of three-spined stickleback and black goby in summer, and of two-spotted goby and three-spined stickleback in the autumn. According to Hop et al. (1992), both black and two-spotted goby are frequently preyed upon by medium-sized cod (150-450 $\mathrm{mm}$ ) in the Norwegian Skagerrak. Gadoid species up to a size of $250 \mathrm{~mm}$ occupying Zostera habitats on the Swedish west coast prey to a large extent upon gobies, whereas sticklebacks are rare in top predatory fish 
stomachs (Wennhage \& Pihl 2002). The rich occurrence of filamentous algae in Zostera beds during recent years may have promoted three-spined sticklebacks by providing them with additional refuge and breeding grounds (Wennhage \& Pihl 2007).

The reduced predation pressure from top predators (mainly cod) is probably the main reason for the general increase in intermediate fish predators in the Zostera habitat (Svedäng \& Bardon 2003, Ask \& Westerberg 2009). However, nine-spined sticklebacks have almost disappeared, and the reason behind their disappearance is as yet unknown. As far as we know, they have not been reported as food items for top predatory fish on the Swedish west coast (Wennhage \& Pihl 2002). The 2 species of stickleback are known to exhibit resource partitioning (Delbeek \& Williams 1987), but the preferred habitat of the nine-spined stickleback is more brackish than that of the three-spined stickleback. A change in salinity is another possible explanation for the shift in dominance amongst sticklebacks, but unfortunately, no data exist for salinity changes in surface water from this period. The food choice of the dominant intermediate predatory fish species in seagrass shows that they are able to consume mesoherbivores $>7 \mathrm{~mm}$, but at present they are mainly feeding on smaller amphipods and meiofauna, as the larger mesoherbivores are rare or missing. No data are available with respect to the food choice of intermediate predatory fish in the 1980s. The disappearance of mesoherbivores in present-day seagrass could be the result of high predation pressure that rarely allows species such as idoteids and gammarids to reach adult size.

Numbers of omnivorous grass shrimps Palaemon adspersus and $P$. elegans and green crabs Carcinus maenas did not change over the investigated period. Interestingly, the ratio between the 2 shrimp species has shifted in favour of $P$. elegans, which is a more generalistic species occurring in rock pools and intertidal sandy bottoms, as well as in non-tidal Zostera beds (Berglund 1982). P. elegans is also more tolerant of high temperatures, especially in combination with extreme salinities and low oxygen concentrations (Berglund 1980, Berglund \& Bengtsson 1981). It is therefore likely that the observed shift in dominance between the 2 species is due to increased water temperatures since the mid-1980s and occurrence of filamentous algae in the Zostera meadows, which causes nocturnal hypoxia when respiration exceeds photosynthesis (Johnson \& Welsh 1985, Amund 2009).

During the 1980s, gammarids and idoteids were the dominant mesoherbivores in Zostera habitats on the Swedish west coast, with abundances of around
30 to 90 ind. $\mathrm{m}^{-2}$ (Baden \& Pihl 1984). Our results show that the mesoherbivore trophic level in Zostera meadows has been reduced dramatically over the last 3 decades to less than 1 ind. $\mathrm{m}^{-2}$. This is in contrast to the 2 Zostera habitats in the northern Öresund, which has a healthy top predator population and about 40 adult mesoherbivores per $\mathrm{m}^{2}$. In the Baltic, adult mesoherbivores may reach densities of several hundred per $\mathrm{m}^{2}$ in the southern Baltic to several thousand per $\mathrm{m}^{2}$ in the mid-Baltic Zostera meadows, leaving the seagrass clean of epiphytes (Bobsien 2006, Jephson et al. 2008, Baden et al. 2010). Stocks of top predators in the Baltic are recovering, but remain decimated compared to the levels of some decades ago (Österblom et al. 2007, Casini et al. 2008). The high abundance of mesoherbivores in mid-Baltic Zostera meadows and the depleted levels in the Skagerrak may both be the result of changes to the abundance of top predators since the 2 systems differ in trophic structure (Baden et al. 2010).

Gammarid adult mesoherbivores were last recorded in the studied Zostera beds on the Swedish west coast in 1986 and were not present at all in 1997. The idoteids have become rare since the late 1980s. Adult idoteids and gammarids are important and efficient mesoherbivores of filamentous green algae and can consume about 14 to $17 \mathrm{mg}$ wet wt Cladophora spp. ind. ${ }^{-1}$ in $48 \mathrm{~h}$ (Jephson et al. 2008, Moksnes et al. 2008, Andersson et al. 2009). Both idoteids and gammarids are still present in the neighbouring Fucus spp. closer to shore, but mesoherbivores $>3 \mathrm{~mm}$ are currently rare in seagrass on the Swedish west coast (Pavia et al. 1999, Jephson et al. 2008), most likely because of the high abundance of intermediate predators (present study). Concordant cage experiments carried out in Zostera beds on the Swedish west coast have shown that where intermediate predatory fish were present and predated on mesoherbivores, a bloom of filamentous green algae occurred (Moksnes et al. 2008). The bloom was accentuated when combined with nutrient enrichment. However, when predation was excluded using a $1 \mathrm{~mm}$ mesh cage, a settlement of gammarids occurred whose members were able to grow to adult size. In these treatments, the abundance of mesoherbivores was comparable to the 1980s, and less filamentous algae were found (Moksnes et al. 2008, Baden et al. 2010).

An additional food resource for intermediate predators and omnivores is the leaf fauna found on Zostera (mean body size of about $3 \mathrm{~mm}$ ), which is mainly composed of small amphipod species and harpacticoids, but also small gastropod species dominated by rissoid snails and the occasional mass 
occurrence $\left(10^{4}\right.$ ind. $\left.\mathrm{m}^{-3}\right)$ of newly settled Mytilus edulis (Baden 1990). The importance of leaf fauna in the diet of intermediate predators and omnivores has been well documented (Wennhage \& Pihl 2002, Bobsien 2006, Jephson et al. 2008) and is confirmed by present study. Historical data from 1 of the studied Zostera locations indicate a decrease in abundance of small leaf fauna amphipods, from $42 \times 10^{3}$ and $35 \times 10^{3}$ ind. $\mathrm{m}^{-2}$ in 1985 and 1997, respectively, to $25 \times 10^{3}$ ind. $\mathrm{m}^{-2}$ in 2004, inhabiting the same biomass of Zostera (Baden 1990, Jephson et al. 2008, S. Baden unpubl.). The small gastropod species, however, maintained about the same level of abundance over this time period, around (1 to 2) $\times 10^{3}$ ind. $\mathrm{m}^{-2}$. Thus, it appears that Zostera leaf fauna (especially crustaceans) has also experienced increased predation pressure from the intermediate predator and omnivore trophic levels.

\section{CONCLUSION}

Despite the imbalance in sampling that often characterises historical data, there are definite indications that a shift in food web structure has taken place over the last 3 decades in Swedish west coast Zostera habitat, in which the effects of a loss of top predators has pushed the balance between trophic levels towards a new state. When sampling today, one generally finds fewer top predatory fish, more intermediate predators and fewer herbivores. It is probable that this shift is partly responsible for the increased production of filamentous algae, especially when combined with the eutrophication documented in the area (Fig. 3). The exact mechanisms of how and when the herbivores fail to control the algal growth remain unclear, but an on-going study suggests that temporal match-mismatch scenarios and system seasonal productivity may be involved (C. J. Svensson et al. unpubl.). At the very least, it can be said that the existing eutrophication has not created any increased consumer response (bottom-up effect), as herbivores are decreasing in number. Understanding the relative proportion of top-down (overfishing) and bottom-up (nutrient) effects responsible for blooms of damaging filamentous algae is of direct importance to stakeholders. From relatively few studies in seagrass, Burkepile \& Hay (2006) modelled this interaction and preliminarily concluded that top-down effects may be of equal or greater significance than bottom-up effects. These historical data reviews, together with future experiments, will hopefully provide a basis for even better explanatory models.

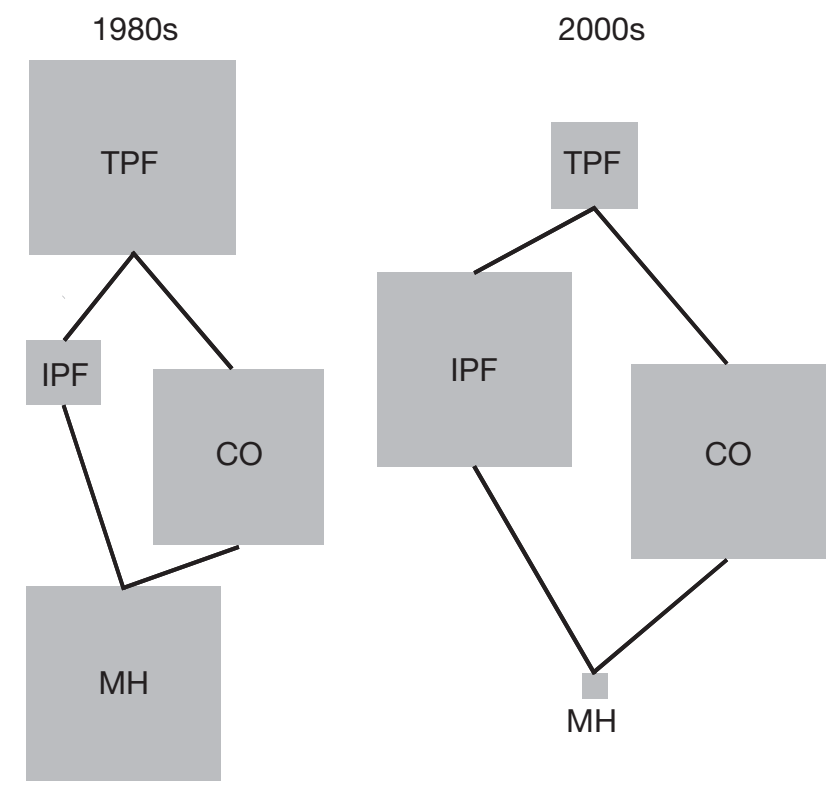

Fig 3. Relative change in biomass between the 1980s and 2000s for each of the trophic levels, top predatory fish (TPF), intermediate predatory fish (IPF), crustacean omnivores (CO) and mesoherbivores (MH). The surface of the smallest square on each trophic level indicates the percentage biomass of the largest biomass square, which represents $100 \%$

Acknowledgements. This study was financed by FORMAS no. 217-2007-1114 to P.Å., S.B. and C.J.S. We are grateful for the field assistance provided during 2008 by G. Ulvros, A. Björnsdotter, A. Emanuelsson, A. Emanuelsson, D. Hinzmann, N. Lundquist, C. Nyström, E. Pihl and S. Svantesson. We thank W. Thornedyke for English grammar correction.

\section{LITERATURE CITED}

Amund AEB (2009) Har isvintrerna förändrats? Havet (The sea). The environmental conditions in Swedish coastal waters 12-15 (in Swedish). Available at www.havet.nu

Andersson PM, Andersson LS (2006) Long term trends in the sea surrounding Sweden. Part 1. Nutrients. Report No. 34, 2006. Swedish Meteorological and Hydrological Institute, Gothenburg

Andersson S, Persson M, Moksnes PO, Baden S (2009) The role of the amphipod Gammarus locusta as a grazer on macroalgae in Swedish seagrass meadows. Mar Biol 156: 969-981

Ask L, Westerberg H (eds) (2009) Fiskbestånd och miljö i hav och sötvatten. Resurs- och miljööversikt. Swedish Fisheries Investigation, Gothenburg

Baden SP (1990) Cryptofauna of Zostera marina (L.): abundance, biomass and population dynamics. Neth J Sea Res 27:81-92

Baden SP, Pihl L (1984) Production. abundance and biomass of mobile epibenthic fauna in Zostera marina meadows. Ophelia 23:65-90

Baden SP, Gullström M, Lundén B, Pihl L, Rosenberg R (2003) Vanishing seagrass (Zostera marina L.) in Swedish coastal waters. Ambio 32:374-377 
Baden SP, Boström C, Arponen H, Tobiasson S, Moksnes PO (2010) Relative importance of trophic interactions and nutrient enrichment in seagrass ecosystems: a broadscale field experiment in the Baltic-Skagerrak area. Limnol Oceanogr 55:1435-1448

Beesley LS, Gilmour JP (2008) A modified drop net for sampling fish communities in complex habitats: a description and comparison with other techniques. N Am J Fish Manag 28:1214-1222

Berglund A (1980) Niche differentiation between two littoral prawns in Gullmar Fjord, Sweden: Palaemon adspersus and P. squilla. Holarct Ecol 3:111-115

> Berglund A (1982) Coexistence, size overlap and population regulation in tidal vs. non-tidal Palaemon prawns. Oecologia 54:1-7

Berglund A, Bengtsson J (1981) Biotic and abiotic factors determining the distribution of two prawn species: Palaemon adspersus and $P$. squilla. Oecologia 54:1-7

Bobsien IC (2006) The role of small fish species in eelgrass food webs of the Baltic Sea. PhD thesis, ChristianAlbrechts-University, Kiel

Boesch DF, Carstensen J, Paerl HW, Skjoldal HR, Voss M (2008) Eutrophication of the seas along Sweden's west coast. Report no. 5898. The Swedish Environmental Protection Agency, Stockholm

> Borum J, Pedersen O, Greve TM, Francovich TA, Zieman JC, Fourqurean JW, Madden CJ (2005) The potential role of plant oxygen and sulphide dynamics in the die-off events of the tropical seagrass Thalassia testudinum. J Ecol 93:148-158

Burkepile DE, Hay ME (2006) Herbivore vs. nutrient control of marine primary producers: context-dependent effects. Ecology 87:3128-3139

Casini M, Lövgren J, Hjelm J, Cardinale M, Molinero JC, Korlinovs G (2008) Multi-level trophic cascades in a heavily exploited open marine ecosystem. Proc R Soc Lond B Biol Sci 275:1793-1801

> Connolly RM (1994) Comparison of fish catches from a buoyant pop net and a beach seine net in a shallow seagrass habitat. Mar Ecol Prog Ser 109:305-309

> Costanza R, d'Arge R, de Groot R, Farber S and others (1997) The value of the world's ecosystem services and natural capital. Nature 387:253-260

> Delbeek JC, Williams DD (1987) Resource partitioning between sympatric populations of brackish water sticklebacks. J Anim Ecol 56:949-967

den Hartog C (1970) The seagrasses of the world. Verh Kon Ned Akad Wet Avd Natuurk Ser II 59:1-275

Diaz RJ, Rosenberg R (2008) Spreading dead zones and consequences for marine ecosystems. Science 321:926-929

Duarte CM, Borum J, Short FT, Walker DI (2008) Seagrass ecosystems: their global status and prospects. In: Polunin NVC (ed) Aquatic ecosystems. Trends and global prospects. Cambridge University Press, Cambridge, p 281-294

Duffy JE, Hay ME (2000) Strong impacts of grazing amphipods on the organisation of a benthic community. Ecol Monogr 70:237-263

Eriksson BK, Ljunggren L, Sandström A, Johansson G and others (2009) Declines in predatory fish promote bloomforming macroalgae. Ecol Appl 19:1975-1988

Frank KT, Petrie B, Choi JS, Leggett WC (2005) Trophic cascades in a formerly cod-dominated ecosystem. Science 308:1621-1623

Green EP, Short FT (2003) World atlas of seagrasses. University of California Press, Berkeley, CA
Harvey CJ, Cox SP, Essington TE, Hansson S, Kitchell JF (2003) An ecosystem model of food web and fisheries interaction in the Baltic Sea. ICES J Mar Sci 60:939-950

Hauxwell J, Cebriàn J, Furlong C, Valiela I (2001) Macroalgal canopies contribute to eelgrass (Zostera marina) decline in temperate estuarine ecosystems. Ecology 82: 1007-1022

Hauxwell J, Cebrian J, Valiela I (2003) Eelgrass Zostera marina loss in temperate estuaries: relationship to landderived nitrogen loads and effect of light limitation imposed by algae. Mar Ecol Prog Ser 247:59-73

> Heck KL, Pennock JR, Valentine JF, Coen LD, Sklenar SA (2000) Effects of nutrient enrichment and small predator density on seagrass ecosystems: an experimental assessment. Limnol Oceanogr 45:1041-1057

Holmer M, Bondgaard EJ (2001) Photosynthetic and growth response of eelgrass to low oxygen and high sulfide concentrations during hypoxic events. Aquat Bot 70:29-38

Holmer M, Baden S, Boström C, Moksnes PO (2009) Regional variation in eelgrass (Zostera marina) morphology, production and stable sulfur isotopic composition along the Baltic Sea and Skagerrak coasts. Aquat Bot 91:303-310

Hop H, Gjøsæeter J, Danielsson DS (1992) Seasonal feeding ecology of Atlantic cod (Gadus morhua L.) on the Norwegian Skagerrak coast. ICES J Mar Sci 49:453-461

Hop H, Gjøsæter J, Danielsson DS (1994) Dietary composition of sympatric cod, Gadus morhua L., and juvenile whiting Merlangius merlangus L., in a fjord of southern Norway. Aquac Fish Manag 25:49-64

> Hughes AR, Bando KJ, Rodriguez LF, Williams SL (2004) Relative effects of grazers and nutrients on seagrasses: a meta-analysis approach. Mar Ecol Prog Ser 282:87-99

> Jackson JB, Kirby MX, Berger WH, Bjorndal KA and others (2001) Historical overfishing and the recent collapse of coastal ecosystems. Science 293:629-637

> Jephson T, Nyström P, Moksnes PO, Baden SP (2008) Trophic interactions in Zostera marina beds along the Swedish coast. Mar Ecol Prog Ser 369:63-76

Johannesson T, Sollie A (1994) Overvåking av gruntvannsfauna på Skagerakkysten (Monitoring of shallow fauna along the Norwegian coast of Skagerrak). Fisken Havet 10:1-91

> Johnson DA, Welsh BL (1985) Detrimental effects of Ulva lactuca (L.) exudates and low oxygen on estuarine larvae. J Exp Mar Biol Ecol 86:73-83

Karlsson C (2009) Utbredning av snabbväxande makroalger i relation till belastning av kväve och fosfor i regionen Orust-Tjörn. MS thesis, University of Gothenburg, Gothenburg

> Lindegren M, Diekmann R, Mölleman C (2010) Regime shifts, resilience and recovery of a cod stock. Mar Ecol Prog Ser 402:239-253

> McGlathery KJ (1995) Nutrient and grazing influences on a subtropical seagrass community. Mar Ecol Prog Ser 122: $239-252$

Moksnes PO, Gullström M, Tryman K, Baden SP (2008) Trophic cascades in a temperate seagrass community. Oikos 117:763-777

Nyberg P, Degerman E (1988) Standardized fish sampling with survey-nets. Contrib No. 7. Freshwater Research Laboratory, Drottningholm (in Swedish with English summary)

> Nyqvist A, André C, Gullström M, Baden SP, Åberg P (2009) Dynamics of seagrass meadows on the Swedish Skagerrak coast. Ambio 38:85-88 
Oksanen L, Fretwell SD, Arruda J, Niemelä P (1981) Exploitation ecosystems in gradients of productivity. Am Nat 118:240-261

Orth RJ, Carruthers TJB, Dennison WC, Duarte CM (2006) A global crisis for seagrass ecosystems. Bioscience 56: 987-996

Österblom H, Hansson S, Larsson U, Hjerne O, Wulff F, Elmgren R, Folke C (2007) Human-induced trophic cascades and ecological regime shifts in the Baltic Sea. Ecosystems 10:877-889

Pavia H, Carr H, Åberg P (1999) Habitat and feeding preferences of crustacean mesoherbivores inhabiting the brown seaweed Ascophyllum nodosum (L.) Le Jol, and its epiphytic macroalgae. J Exp Mar Biol Ecol 236:15-32

Pihl L (1982) Food intake of young cod and flounder in a shallow bay on the Swedish west coast. Neth J Sea Res 22:169-179

Pihl L, Rosenberg R (1982) Production, abundance and biomass of mobile epibenthic marine fauna in shallow waters, western Sweden. J Exp Mar Biol Ecol 57:273-301

Pihl L, Svenson A, Moksnes PO, Wennhage H (1999) Distribution of green algal mats throughout shallow soft bottoms of the Swedish Skagerrak archipelago. J Sea Res 41:281-294

Pihl L, Baden S, Kautsky N, Rönnbäck P, Söderqvist T, Troell M, Wennhage H (2006) Shift in fish assemblage structure due to loss of seagrass habitats. Estuar Coast Shelf Sci 67: 123-132

Rönnbäck P, Kautsky N, Pihl L, Troell M, Söderqvist T, Wennhage H (2007) Ecosystem goods and services from Swedish coastal habitats: identification, valuation, and implications of ecosystem shifts. Ambio 36:534-544

Rosenberg R, Elmgren R, Fleischer S, Jonsson P, Persson G,

Editorial responsibility: Kenneth Heck, Dauphin Island, Alabama, USA
Dahlin H (1990) Marine eutrophication case studies in Sweden. Ambio 3:102-108

Rumohr H, Brey T, Ankar S (1987) Compilation of biometric conversion factors for benthic invertebrates of the Baltic sea. Publ No. 9. The Baltic Marine Biologists, Uppsala

Svedäng H (2010) Long-term impact of different fishing methods on the ecosystem in the Kattegat and Öresund. EU note. Directorate-general for internal policies, Policy department B, Structural and cohesion policies, Fisheries. European Parliament, Brussels; www.europarl. europa.eu/studies

Svedäng H, Bardon G (2003) Spatial and temporal aspects of the decline in cod (Gadus morhua L) abundance in the Kattegat and eastern Skagerrak. ICES J Mar Sci 60: 32-37

Svedäng H, Svenson A (2006) Cod Gadus morhua L. populations as behavioural units: inference from time series on juvenile abundance in the eastern Skagerrak. J Fish Biol 69:151-164

Valentine J, Duffy JE (2006) The central role of grazing in seagrass ecology. In: Larkum WD, Orth RJ, Duarte CM (eds) Seagrasses: biology, ecology and conservation. Springer, Dordrecht, p 463-501

Waycott M, Duarte C, Carruthers T, Orth RJ and others (2009) Accelerating loss of seagrasses across the globe threatens coastal ecosystems. Proc Natl Acad Sci USA 106:12377-12381

> Wennhage H, Pihl L (2002) Fish feeding guilds in shallow rocky and soft bottom areas on the Swedish west coast. J Fish Biol 61:207-228

Wennhage H, Pihl L (2007) From flatfish to sticklebacks: assemblage structure of epibenthic fauna in relation to macroalgal blooms. Mar Ecol Prog Ser 335:187-198

Submitted: December 20, 2011; Accepted: January 4, 2012 Proofs received from author(s): March 30, 2012 